\title{
James Cooley Fletcher, 0 missionário amigo do Brasil
}

James Cooley Fletcher, the

Missionary Friend of Brazil

\section{Bruno Gonçalves Rosi \\ Professor auxiliar no Instituto Universitário de Pesquisas do Rio de Janeiro (IUPERJ) e doutorando em Ciência Política pela Universidade do Estado do Rio de Janeiro (IESP/ UERJ - Rio de Janeiro/Brasil). e-mail:bruno_rosi@hotmail.com}

\author{
Resumo \\ James Cooley Fletcher (1823-1901) foi um pastor presbiteriano que \\ atuou como missionário, diplomata e lobista no Brasil entre 1852 e 1869. \\ Tornou-se conhecido especialmente pela autoria do livro 0 Brasil e os \\ Brasileiros: Esboço Histórico e Descritivo, de 1857, a principal referência a \\ respeito do pais nos Estados Unidos até então. Fletcher é um autor muitas \\ vezes citado, mas pouco compreendido. 0 principal objetivo deste artigo \\ é tornar este personagem conhecido, ou ao menos detalhar melhor sua \\ vida e especialmente sua passagem pelo Brasil. Em outras palavras, este \\ artigo é uma breve narrativa da vida do pastor James Cooley Fletcher, \\ especialmente de sua atuação no Brasil.
}

\begin{abstract}
James Cooley Fletcher (1823-1901) was a Presbyterian clergyman who served as a missionary, diplomat and lobbyist in Brazil between 1852 and 1869. He became especially known for authoring the book Brazil and Brazilians: Historical and Descriptive Sketches, 1857, which became the main reference about the country in the United States so far. Fletcher is an author often quoted but little understood. The main objective of this paper is to make this character better known, or at least to better detail his life and especially the years of his trip to Brazil. That is, this article is a brief narrative of the life of Preacher James Cooley Fletcher, especially during his years in Brazil.
\end{abstract}

Palavras-chave

James Cooley Fletcher, protestantismo, Brasil, Estados Unidos

Keywords

James Cooley Fletcher, protestantism, Brazil, United States 
BRAGA, Erasmo; GRUBB, Kenneth G. The Republic of Brazil: a survey of the religious situation. London: World Dominion Press, 1932.

2

VIEIRA, David Gueiros. O Protestantismo, a Maçonaria e a Questão Religiosa no Brasil. Brasilia: Editora Universidade de Brasília, 1980. p.62.

3

FREYRE, Gilberto. Order and Progress: Brazil from Monarchy to Republic. Berkley and Los Angeles: University of California Press, 1986. p.325.

4

JAMES, David. 0 Imperador do Brasil e os seus Amigos da Nova Inglaterra. In: Anuário do Museu de Petrópolis, Volume XIII. Petrópolis: Ministério da Educação e Saúde, 1952. p.22. 5

CARVALHO, José Murilo de. Dom Pedro II. São Paulo: Companhia das Letras, 2007. p.157-159.

6

VIEIRA, David Gueiros. Op. Cit., p.62.
Introdução

No início do século XIX, não se observava no Brasil qualquer vestígio de protestantismo. Ao final do século, porém, diversos grupos protestantes encontravam-se em atividade no país, alguns dos quais em nível avançado de organização. Havia cerca de 200 igrejas organizadas, e até a década de 1930 os evangélicos seriam 1 milhão de pessoas (se considerados os luteranos descendentes de alemães) em uma população de cerca de 40 milhões. ' Durante esse período, missionários provenientes especialmente dos Estados Unidos e Europa estabeleceram trabalhos junto a brasileiros e imigrantes, plantando uma semente para o desenvolvimento de uma igreja evangélica brasileira.

James Cooley Fletcher foi um pioneiro do trabalho protestante missionário no Brasil e um dos que, muito ativamente, contribuíram para o movimento de protestantização do Império e para a luta em favor da completa liberdade de culto. ${ }^{2}$ Para Gilberto Freyre ele foi um observador confiável de muitos aspectos da sociedade brasileira do século XIX. ${ }^{3}$ David James o considera o primeiro dos "amigos da Nova Inglaterra" de $d$. Pedro II. ${ }^{4}$ Indo mais a fundo, José Murilo de Carvalho destaca o papel de Fletcher na crescente admiração do imperador pelos Estados Unidos. ${ }^{5}$ São descrições de grande importância, porém, nas palavras de David Gueiros Vieira, Fletcher é um autor "muitas vezes citado, ainda que pouco compreendido"6.

Acredito que as descrições destes autores são corretas. Mais importante, acredito que a observação de Vieira é pertinente e permanece atual. Fletcher continua sendo mencionado em trabalhos acadêmicos, mas de maneira bastante pontual e nem sempre acurada. Uma narração biográfica detalhada ou uma análise aprofundada de seu papel no Brasil nunca são realizadas (salvo pelos trabalhos do próprio David Gueiros Vieira e de David James). Por exemplo: o Dicionário do Brasil Imperial organizado por Ronaldo Vainfas não traz um verbete a seu respeito, embora Daniel Kidder, colega metodista de Fletcher, tenha feito jus a um. No Dicionário, Fletcher é apenas brevemente mencionado como mais um entre diversos viajantes que pelo Brasil passaram nos oitocentos, sem que sua importância seja notada. Não há uma biografia em português a seu respeito. Em meu levantamento, não consegui encontrar sequer um artigo em português especificamente sobre este personagem. Mesmo entre os presbiterianos (denominação a que Fletcher pertencia), ou evangélicos de modo geral, o papel deste personagem carece de maior atenção. Nas recentes comemorações do sesquicentenário do presbiterianismo no Brasil, em 2009, seu nome pouco foi mencionado. Livros contando a história do protestantismo no Brasil dificilmente dedicam-Ihe maior atenção.

Assim sendo, o principal objetivo deste artigo é tornar este personagem conhecido, ou ao menos detalhar melhor sua vida e especialmente sua passagem pelo Brasil. Ou seja, este artigo é uma breve narrativa da vida do pastor James Cooley Fletcher, especialmente de sua atuação no Brasil.

As divisões do artigo foram pensadas principalmente em função das diferentes viagens feitas por Fletcher ao Brasil. Uma seção trata dos anos formativos antes de sua primeira viagem. As atividades em que ele se envolveu foram numerosas e variadas. Este artigo não trata de todas e nem o faz de forma exaustiva. Há uma preocupação em relatar as atividades em ordem cronológica, dando base para futuros estudos mais detalhados e analíticos. 
Informações obtidas através da Indiana Historical Society. http://www.indianahistory.org/ library/manuscripts/collection_guides/M0108. html. Acesso em 22 de setembro de 2012.

8

A Igreja Presbiteriana, a que Fletcher pertencia, é uma igreja protestante ou evangélica, com raizes na Reforma Protestante do século XVI e mais precisamente em João Calvino. Possui como base uma teologia calvinista ou reformada, expressa na Confissão de Fé de Westminster. Entre suas características centrais estão uma soteriologia calvinista e a forma de governo presbiteriana, ou seja, através de anciãos escolhidos pela assembleia das igrejas locais, em oposição ao governo episcopal ou ao governo congregacional de outras igrejas evangélicas. Ver HODGE, Charles. What is Presbyterianism?: An address delivered before the Presbyterian historical society at their anniversary meeting in Philadelphia, on Tuesday evening, May 1, 1855. Philadelphia: Presbyterian board of publication, 1855.

9

Samuel Miller (1769-1850) concentrava-se em História Eclesiástica e Eclesiologia. Joseph Addison Alexander (1809-1860), terceiro filho de Archibald Alexander, foi um notável exegeta e linguista. Charles Hodge (1797-1878) destacouse na Teologia Sistemático e foi diretor do seminário por muitos anos. Archibald Alexander (1772-1851) foi diretor do seminário por 27 anos, de 1812 a 1840 . Cada um destes mencionados foi autor de diversos livros. DULLES, Joseph $\mathrm{H}$. Princeton Theological Seminary Biographical Catalogue, 1909. Trenton, New Jersey: MacCrellish \& Quigley, Printers, 1909. p.17.

10

KIDDER, D. P.; FLETCHER, J. C. Brazil and the Brazilians, portrayed in Historical and Descriptive Sketches (9a.ed.). Philadelphia: Childs \& Peterson, 1879. p.138.

11

GAYLE, Thornbrough; RIKER, Dorothy; CORPUZ, Paula (eds.). The Diary of Calvin Fletcher, Vol. IV, 1848-1852, Including Letters to and from Calvin Fletcher. Indianapolis: Indiana Historical Society, 1975. p.135.

12

JAMES, David. Op. Cit., p.23
Primeiros anos

0 pastor James Cooley Fletcher nasceu em Indianápolis, Indiana, em 15 de Abril de 1823, somente três anos após a fundação da cidade e sete após aquele Estado tornar-se parte da União. Ele era o mais velho de onze irmãos, filho de Sarah Hill (1801-1854) e Calvin Fletcher (1798-1866).

Calvin era um destacado cidadão local: foi senador, advogado, homem de negócios e fazendeiro. Era também membro ativo de diversas organizações da cidade. Chegou a Indianápolis em 1821 com sua esposa, sendo eleito procurador para a jurisdição do Condado de Marion pouco após. Em 1834 foi designado diretor do Banco do Estado e comissário do fundo de amortização. Chegou a organizar seu próprio banco com Thomas Sharpe, o Indianapolis Branch Banking Co., também conhecido como Fletcher and Sharpe Bank?

Embora formalmente (e ativamente) metodista, Calvin participava de atividades de muitas igrejas e organizações interdenominacionais. Foi professor, superintendente e palestrante de Escola Dominical na Roberts Chapel e outros lugares. Curiosamente, um dos filhos de Calvin e Sarah, Elijah (nascido em 1824), tornou-se pastor da igreja metodista quase ao mesmo tempo em que James se tornava da presbiteriana. ${ }^{8}$

Aparentemente, Cooley (como era chamado entre os familiares) foi batizado em homenagem a James Cooley, professor de direito do pai em Urbana, Ohio. Após estudar em diversas escolas locais, o jovem Fletcher foi enviado para a Philips Academy, em New Hampshire, onde realizou os preparatórios para ingressar na faculdade. Assim como vários de seus irmãos, ingressou na Brown University, de Providence, Rhode Island, onde graduou-se em 1846.

Em 1847, tendo decidido se dedicar ao ministério, Fletcher ingressou no Seminário de Princeton. Possivelmente foi aluno de Samuel Miller, Joseph Addison Alexander, Charles Hodge e Archibald Alexander, alguns dos principais teólogos calvinistas de seu tempo. ${ }^{9}$ Dois anos depois, em 1849, transferiu-se para a Europa visando aperfeiçoar seu domínio da língua francesa a fim de tornar-se um dia missionário no Haiti. Completou seus estudos em Paris e Genebra, nesta como aluno de Jean-Henry Merle d'Aubigne, historiador da Reforma Protestante muito lido nos Estados Unidos naquele tempo. Entre outras experiências vividas na Europa, teve a oportunidade de encontrar-se com Alexis de Tocquevile em Paris ${ }^{10}$ e de participar do encontro do Congresso Internacional da Paz na mesma cidade em 1849, como correspondente para o jornal Observer de Nova York. ${ }^{11}$ Durante esta etapa de estudos casou-se com Henriette, filha de César Malan, teólogo calvinista de Genebra, e em 1850 retornou aos Estados Unidos com a esposa.

Pouco tempo após seu retorno aos EUA Fletcher foi ordenado pelo presbitério de Muncie, Indiana, em 13 de fevereiro de 1851. No mesmo ano foi enviado ao Rio de Janeiro como missionário da American and Foreign Christian Union e capelão da American Seamen's Friend Society em uma missão que duraria até 1854. Seu objetivo seria atender aos norte-americanos residentes na corte brasileira e aos marinheiros norte-americanos que passavam pelo porto do Rio de Janeiro.

\section{Primeira viagem ao Brasil (1852-1854)}

Cooley chegou ao Rio de Janeiro com a esposa Henriette e o filho Edmond em 14 de Fevereiro de $1852 .{ }^{12}$ Esta missão e suas atividades religiosas foram negociadas com o governo brasileiro por Robert Cumming Schenck, 
13

STEWART, C. S. Brazil and La Plata: The Personal Record of a Cruise. New York: G. P. Putnam \& Co. 1856. p.399-400.

14

Indiana Historical Society - Calvin Fletcher Papers, Carta $n^{\circ} 493$.

15

CARVALHO, José Murilo de. Op. Cit., p.157-159.

16

KIDDER, D. P.; FLETCHER, J. C. Op. Cit., 9a ed., p.237-238.

17

Indiana Historical Society - Calvin Fletcher

Papers, carta $n^{\circ} 849$.
Enviado Extraordinário e Ministro Plenipotenciário dos Estados Unidos para o Brasil e Argentina (entre 1851 e 1853). Schenck nomeou Fletcher Capelão da Legação Americana, com o título de "Adido", dando-Ihe dessa maneira proteção oficial. Pouco tempo após sua chegada, o missionário recebeu de seu vizinho e amigo Ferdinand Coxe, Secretário da Legação, o pedido para substituí-lo. Dessa maneira o pastor tornou-se Secretário Interino da Legação, trabalhando sob as ordens de Edward Kent, cônsul americano na corte e Charge d'Affaires na ausência de Schenck. ${ }^{13}$

Na interpretação do David Gueiros (1980), naquele momento, Fletcher parece ter chegado à conclusão de que seu dever e sua responsabilidade não eram apenas ser pastor dos marinheiros e dos americanos residentes no Rio, mas também evangelizar os brasileiros. Essa mudança de mentalidade, de capelão de marítimos para a de missionário, é claramente indicada em uma carta de doze páginas, escrita a Calvin Fletcher, seu pai. Fletcher, nesta carta, começava a formular o que parece ter-se tornado seu plano de ação e por algum tempo sua grande obsessão: converter 0 Brasil ao protestantismo e ao "progresso". A partir de seus escritos pode ser deduzido que para ele o protestantismo equalizava-se ao desenvolvimento econômico, científico e tecnológico. ${ }^{14}$

Os cargos ocupados na Legação entre julho de 1852 e outubro de 1853 deram-Ihe a oportunidade de fazer amigos na Corte, quase todos indivíduos de tendências liberais que favoreciam causas advogadas por ele, especialmente a liberdade de culto. 0 círculo de amizades de Fletcher no Rio de Janeiro é chamado por David Gueiros de "brasileiros amigos do progresso". Um dos pontos altos deste período se deu em setembro de 1852, quando Ihe foi designada a tarefa de guiar o imperador em uma visita ao City of Pittsburg, um vapor mercante norte-americano ancorado no porto do Rio a caminho da Califórnia. Foi seu primeiro encontro com Dom Pedro II.

Segundo Fletcher descreve, Dom Pedro II ficou maravilhado com o navio, examinando os mínimos detalhes de seu funcionamento. Fletcher o seguia de perto, usando seus dotes linguísticos - ninguém na Legação além dele sabia falar francês ou português - para fornecer informações servindo de mediador entre o imperador e os oficiais norte-americanos. De acordo com José Murilo de Carvalho, este foi o início do "caso de amor [de D. Pedro II] com os Estados Unidos"15. A ocasião parece ter sido bastante marcante para o missionário também, pois ele menciona que em seu breve retorno aos Estados Unidos, em 1854, foi iniciado o trabalho que the tomaria muitos anos, o de aproximar os dois paises, retirando os entraves da ignorância mútua que impediam contatos mais próximos entre eles. ${ }^{16}$

Robert C. Schenck, o diplomata amigo do missionário, foi substituído em 1853 por William Trousdale (1853-1857). Trousdale, ao contrário de Schenck, não foi acessivel à Fletcher e aos seus conselhos. 0 missionário ficou pasmo com os modos grosseiros e com a desastrada atuação do novo diplomata. A falta de um amigo na diplomacia pesou para Fletcher. Ele se viu não somente afastado da confiança do ministro americano, mas foi também demitido de seu emprego na Legação. Seu nome desapareceu completamente da lista diplomática da Corte Imperial do ano de 1854. Fletcher tornou-se um crítico de Trousdale. Descrevendo o ministro para seu pai, disse que este era "o palhaço de toda a Corte, do corpo diplomático e de seus próprios patrícios. É um homem que não pede conselho a ninguém e não toma o conselho de ninguém que tente dar-Iho"17. 
18

Ibidem, carta n 819.

19

HERNDON, William Lewis; GIBBON, Lardner. Exploration of the valley of the Amazon: made under direction of the Navy Department by Wm. Lewis Herndon and Lardner Gibbon, Lieutenants United States Navy. Washington: Robert Armstrong, public printer, 1854.

20

HILL, Lawrence F. Diplomatic Relations Between the United States and Brazil. Durham: Duke University Press, 1932. p.218-220; ROSI, B. G. Exploradores, Missionários, Cientistas e a abertura do Amazonas. Conjuntura Austral. Vol.2, 2011. p.77-78.

21

VIEIRA, David Gueiros. Op. Cit., p.95.

22

KIDDER, D. P.; FLETCHER, J. C. Op. Cit., $1^{\text {a }}$ ed.

Philadelphia: Childs \& Peterson, 1857. p.570.
Devido a problemas de saúde de sua esposa, Fletcher precisou retornar aos Estados Unidos entre 1853 e 1854, ali chegando em março deste ano. Seu retorno aos EUA, longe de significar o final de suas atividades a favor da aproximação entre Estados Unidos e Brasil, tornou-se uma oportunidade para intensificar e diversificar sua campanha. Neste período, 0 missionário esteve em Washington, D.C. Em todas as suas atividades ali foi auxiliado por seu amigo Robert Schenck. Esteve junto do presidente Millard Fillmore, a quem considerou "muito afável". 0 presidente acompanhou ainda uma pregação do missionário. ${ }^{18}$

Neste periodo, Washington fervilhava com as idéias de Matthew Fontaine Maury e com notícias a respeito de expedições pelo rio Amazonas, entre elas a Herndon-Gibbon. Francisco Ignácio de Carvalho Moreira, chefe de missão do Brasil nos Estados Unidos (Enviado Extraordinário e Ministro Plenipotenciário, 1852-1855), encontrava-se consternado com o que considerava ser uma ameaça de uma invasão de flibusteiros ao Amazonas.

Oficial da Marinha dos Estados Unidos, oceanógrafo, cartógrafo, astrônomo, geólogo, historiador, entre outras ocupações, Matthew Fontaine Maury abriu caminho para uma expedição ao vale do Amazonas chefiada por seu primo, William L. Herndon, e Lardner Gibbon, também oficiais da marinha norte-americana. De acordo com Maury, as correntes maritimas faziam do Amazonas nada mais do que uma continuação do Mississipi, e abrir o rio sul-americano teria sobre os Estados Unidos o mesmo impacto da compra da Louisiana: a abertura redundaria em progresso para a região de Nova Orleans, para o Sul dos Estados Unidos e, por fim, para todo o pais.

William L. Herndon e Lardner Gibbon iniciaram sua expedição em maio de 1851, a partir dos Andes. 0 resultado da expedição de Herndon e Gibbon foi um amplo e detalhado relatório de mais de quatrocentas páginas. No início de 1853, este relatório foi publicado e submetido ao Congresso pelo próprio presidente dos Estados Unidos, Millard Fillmore. ${ }^{19} \mathrm{Com}$ ampla circulação, o livro teve impacto imediato: logo após sua publicação o comércio entre Estados Unidos e Brasil, através do porto do Pará, teve um grande salto, quase dobrando de valor. ${ }^{20}$

Antes de retornar aos EUA Fletcher suscitara a questão da abertura do Amazonas à navegação internacional através de artigos sobre o assunto nos jornais do Rio de Janeiro ${ }^{21}$, porém suas opiniões eram bastante diversas dessas de Maury, Herndon e Gibbon: por um lado considerava que a abertura do rio ao comércio e navegação internacionais seria um acontecimento sem igual para o comércio internacional..$^{22}$ Ao mesmo tempo avaliava que, embora cientificamente acuradas, as proposições de Maury a respeito do Amazonas e sua navegação atrapalharam a aproximação entre Brasil e Estados Unidos:

Em 1853, uma tradução das cartas do tenente Maury foi publicada no Correio Mercantil, jornal de grande circulação no Rio de Janeiro; e eu lembro bem da comoção que suas comunicações sobre a Amazônia causaram na capital, em conexão com um relatório de que uma expedição de "flibusteiros" estava sendo preparada em Nova York para forçar a abertura do grande rio.

É certamente, uma questão de profundo pesar que alguém cujos escritos e investigações científicas não só receberam os mais altos elogios dos grandes e letrados nos dois continentes, mas que tem abençoado e estão abençoando o mundo, deveriam ter se permitido fazer uso de linguagem que só poderia inflamar uma sensivel nação, e de alguns argumentos que só tendem a "flibusterismo". Se o tenente Maury deixasse de lado a linguagem ofensiva, e uma parte de seu raciocinio, que tem sido legitimamente interpretado por brasileiros como nada menos do que uma defesa da teoria de que o poder define o que é bom, eu acredito que teria sido 
Ibidem. $6^{\text {a }}$ ed. Philadelphia: Childs \& Peterson, 1866. p.579.

25

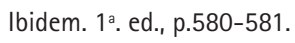

Fundada em 1816, a American Bible Society (ABS) é um grupo que publica, distribui e traduz a Bíblia. É uma das mais antigas Sociedades Bíblicas em atuação. Obtido em http://www. americanbible.org/pages/about-more-history. Acesso em 22 de setembro de 2012.

27

As biblias distribuidas por Fletcher eram fornecidas pelos grupos missionários para os quais trabalhava. Não há nenhuma diferença significativa entre estas bíblias e aquelas sancionadas pela Igreja Católica Romana no Brasil - com exceção dos livros de Tobias, Judite, Sabedoria, Eclesiástico, Baruque, I Macabeus e II Macabeus e as chamadas Adições em Ester e Adições em Daniel, presentes na Bíblia Católica e ausentes na Protestante e na Judaica. No entanto, a distribuição de bíblias por colportores evangélicos (chamadas de "falsas bíblias" por parte do clero católico romano) causou significativa controvérsia em alguns pontos do pais, havendo vários episódios de biblias queimadas em fogueiras públicas. KIDDER, D. P.; FLETCHER, J. C. Op. Cit. 9a ed., p.5, p.422.

28

Ibidem. 9a ed., p.405-413

muito melhor para o nosso país e para o Brasil. Desde aquela ocasião, tem sido impossivel negociar um tratado com o Brasil,-um governo com o qual devemos estar intimamente ligados. Não há reciprocidade entre nós. Enquanto nós recebemos deles grande comércio, livre de impostos, tudo o que é exportado por nós para o Brasil é fortemente tributado. A propriedade de nossos cidadãos morrendo no Brasil é administrada pelo governo brasileiro de uma forma que nunca dá satisfação. Atrocidades cometidas contra os cidadãos dos Estados Unidos, em partes distantes do Império muito tardiamente, ou nunca, são respondidas com reparação pelos magistrados do interior, cujos sentimentos em relação a Norte Americanos foram amargurados pelas conclusões a que chegaram depois de ler as cartas do Tenente Maury. Vai passar muito tempo antes que nós recuperemos as simpatias que tínhamos em 1850, quando foi proposto que, em caso de guerra com a Inglaterra, que todo o comércio na costa brasileira deveria ser colocado sob a bandeira dos Estados Unidos. ${ }^{23}$

Como se vê, Fletcher considerava a linguagem do oceanógrafo "ofensiva", e acreditava que seus escritos não poderiam ter deixado nos brasileiros outra impressão que não a de pirataria. De acordo com o missionário, desde que o trabalho de Maury havia sido publicado, havia sido impossivel negociar um tratado com o Brasil, um Estado com o qual os EUA tinham a extrema necessidade de estabelecer relações mais próximas. Ele também acusa Maury de possuir "curteza de vistas em relação ao seu próprio país"24.

A opinião de Fletcher a respeito da abertura do rio Amazonas pode ser resumida da seguinte maneira: o Brasil, e somente o Brasil, tem o direito de controlar os rios que estejam dentro de suas fronteiras e nenhum país tem o direito de forçá-lo a conceder a livre navegação. Entretanto, seria de incalculável benefício para essa nação, bem como para as nações vizinhas, que o rio se abrisse ao comércio do mundo. ${ }^{25}$ Nos anos seguintes o missionário permaneceria bastante ativo neste debate.

\section{0 amigo da Nova Inglaterra: segunda viagem (1855)}

Em 25 de Abril de 1855 Fletcher estava de volta ao Brasil para uma breve estadia que perduraria até 19 de Julho do mesmo ano, desta vez como agente da American Bible Society. ${ }^{26}$ Neste período viajou quase cinco mil quilômetros Brasil adentro distribuindo Bíblias em português. ${ }^{27}$ Foi também um período no qual ele deixou seu lado filantropo falar mais alto, organizando em 16 de maio uma exposição industrial de produtos norte-americanos no Rio de Janeiro. A exposição foi ainda uma oportunidade para aproximar-se de Dom Pedro II, a quem os industriais norte-americanos enviaram presentes.

Após a exposição, o pastor viajou para as províncias do sul do Brasil, visitando, entre outras cidades, Ubatuba, São Sebastião, São Vicente, Paranaguá, São Francisco do Sul, Joinville, Desterro, Rio Grande do Sul, Campinas e São Paulo. Nestas, distribuiu grande número de Bíblias, inclusive entre imigrantes suiços e alemães luteranos que encontrou na Fazenda Angélica, em São Paulo, colônia de parceria de Nicolau de Campos Vergueiro (1778-1859). Fletcher muito se admirou do sistema empregado, chegando a considerá-lo o método correto para desenvolver o Brasil em população e agricultura, embora os resultados o tenham desapontado ao longo dos anos, fato que atesta na $9^{a}$ edição de seu livro. ${ }^{28}$

De volta ao Rio encontrou-se mais uma vez com o imperador. Conforme descreve David Gueiros, sem nenhuma audiência marcada, Fletcher invadiu o palácio de São Cristóvão durante a festa de aniversário da princesa Leopoldina trazendo consigo vários livros que havia recebido de 
29

Ibidem. 9a ed., p.249-250.

30

VIEIRA, David Gueiros. Op. Cit., p.73.

31

Indiana Historical Society - Calvin Fletcher Papers, Carta n 521.

32

Ibidem. 9a ed., p.250.

33

Ver http://www.presbiterianismo.com.br/ Historia/Funchal.htm. MATOS, A. S. Robert Reid Kalley: Pioneiro do Protestantismo Missionário na Europa e nas Américas. Acesso em 21 de setembro de 2012.

34

VIEIRA, David Gueiros. Op. Cit., p.135.

35

Ibidem, p.163-187. editores dos Estados Unidos. Para sua grande surpresa e alegria, Dom Pedro II o recebeu imediatamente. 0 imperador encontrava-se especialmente esperançoso de através de Fletcher travar contato com Henry Wadsworth Longfellow, um poeta norte-americano de sua predileção. Através do missionário, Dom Pedro II enviou ao poeta o recado "Diga-Ihe o quanto prazer ele me tem dado, como the estimo, como lhe amo"29.

De volta aos Estados Unidos em 1856, Fletcher procurou aproximar-se não apenas de Longfellow, mas também de Louis Agassiz, um dos mais importantes naturalistas de seu tempo, e John Greenleaf Whittier, poeta e abolicionista admirado por d. Pedro II. 0 missionário parece ter deliberadamente planejado tornar-se o mensageiro entre estes sábios e o Imperador. Aparentemente ele também foi responsável pela renovação do interesse do Professor Agassiz pela ictiologia brasileira..$^{30} 0$ resultado foi uma duradoura amizade entre 0 imperador e seus "amigos da Nova Inglaterra", como David James os denomina. A partir de 1863, Fletcher e d. Pedro II iniciaram uma troca de correspondências e visitas que se estenderia até o falecimento deste.

David Gueiros deduz a partir da correspondência entre Fletcher e sua família que o missionário parecia estar fascinado com a ideia hipotética de exercer uma influência política e ética sobre o imperador. Isso era algo que um colega seu, o Reverendo Charles Stewart, capelão da Marinha dos Estados Unidos, alegava haver tido em relação a Luis Bonaparte enquanto este esteve exilado em Nova York. ${ }^{31}$ De fato, o missionário parece ter ensaiado uma evangelização do monarca na ocasião em que se encontraram no palácio em São Cristóvão. Quando discutiam sobre os livros que Fletcher havia levado, o missionário mencionou a obra de John Bunyan. ${ }^{32}$

Pode ser mencionado ainda que em 10 de Maio daquele ano de 1855 chegaram ao Rio de Janeiro Robert e Sarah Kalley, fundadores da Igreja Evangélica Fluminense, geralmente considerada a mais antiga denominação evangélica de língua portuguesa do Brasil. Após uma breve passagem pela capital, o casal se instalou em Petrópolis, onde em 19 de Agosto realizou a primeira aula de Escola Bíblica Dominical do Brasil. A vinda de Robert e Sarah Kalley para o Brasil se deu com importante contribuição de Fletcher: em 1853 ele havia enviado uma carta para a Sociedade Bíblica Americana em Nova York pedindo o envio de alguns refugiados madeirenses para trabalharem no Brasil como colportores. Esta carta acabou interceptada pelos Kalley, que estavam em Illinois visitando os mesmos madeirenses. Kalley foi informado pelo dirigente da Sociedade Bíblica sobre o pedido de Fletcher e decidiu ele mesmo vir para o Brasil no ano seguinte. ${ }^{33}$

Alguns anos depois, em 1859, Ashbel Green Simonton, missionário presbiteriano comissionado pela Presbyterian Church in the United States of America (PCUSA), também chegaria ao Brasil. Portava cartas de apresentação para alguns brasileiros "de alta classe" fornecidas por Fletcher, embora pouco tenha lançado mão destas. ${ }^{34}$ Simonton iria tornar-se o fundador do presbiterianismo brasileiro.

No ano seguinte Richard Holden, missionário episcopal escocês radicado nos EUA, chegaria ao Brasil de maneira não tão diferente destes últimos: com um exemplar de Brasil e os Brasileiros nas mãos e um suprimento de Bíblias na bagagem. Holden iria permanecer no Brasil até 1872, atuando principalmente no Pará. Se tornaria um personagem central da Questão Religiosa da década de $1870 .^{35}$

Por último, ainda falando da contribuição de Fletcher para as missões evangélicas no Brasil, temos seu livro O Brasil e os Brasileiros usado como 
36

Ibidem. 9a ed., p.III.

37

Ibidem. $8^{a}$ ed. Philadelphia: Childs \& Peterson, 1868. p.III.

38

STROBRIDGE, G E. Biography of the Rev. Daniel Parish Kidder, D.D., LL.D. New York: Hunt \& Eaton 1894. p.274.

39

HARTT, Charles Frederick. Geology and physical geography of Brazil. Boston: Fields, Osgood, 1870 BROWN, Hubert W. Latin America: the pagans, the Papists, the patriots, the Protestants and the present problem. New York: Young People's Missionary Movement of the United States and Canada, 1909; GAMMON, Samuel R. The evangelical invasion of Brazil or a half century of evangelical missions in the land of the Southern Cross. Richmond: Presbyterian Committee of Publication, 1910; NORMANO, John Francis. Brazil, a study of economic types. Chapel Hill: The University of North Carolina Press, 1935; MELLOLEITÃO, Cândido. O Brasil visto pelos Ingleses. São Paulo: Companhia Editora Nacional, 1937 RAMOS, Arthur. A aculturação negra no Brasil. São Paulo: Companhia Editora Nacional, 1942.

40

ELLIOT, Lilian Ellwyn. Brazil today and tomorrow. New York: The Macmillan Company, 1917. p.126 (tradução minha).

41

COOPER, Clayton Sedgwick. The Brazilians and their Country. London: William Heinemann, 1919. p.335 (tradução minha).

42

WHEELER, W. Reginald; MCGREGOR, Robert Gardner; GILLMORE, Maria Mcilvaine; REID, Ann Townsend; SPEER, Robert E. Modern Missions in Chile and Brazil. Philadelphia: The Westminster Press, 1926. p.336. referência pelo Board of Foreign Missions da Presbyterian Church USA durante muitos anos (ver o Historical Sketches of Presbyterian Missions, edições de 1891 e 1897).

\section{0 escritor amigo do Brasil: interlúdio nos EUA (1856-1862)}

Fletcher permaneceu nos Estados Unidos de 1856 a 1862, principalmente em Massachusetts. Logo após seu retorno a pátria, atendendo a um pedido feito pelo missionário metodista Daniel Parish Kidder anos antes, começou a trabalhar em 0 Brasil e os Brasileiros: Esboço Histórico e Descritivo, livro que o tornaria famoso. A primeira edição saiu em 1857, e até 1867 já seriam mais seis. 0 livro foi escrito com a ajuda do jornalista e ex-editor do jornal Cincinnati Daily Republican, Dr. Thomas Rainey, que acabara de regressar do Brasil, onde havia visitado Belém e o vale do Amazonas. Frustrado em suas tentativas de estabelecer uma linha de vapores, Rainey permaneceu nos Estados Unidos em 1857, ajudando Fletcher a escrever 0 Brasil e os Brasileiros, ao mesmo tempo em que escrevia seu próprio livro, Ocean Steam Navigation and Ocean Post.

A princípio uma ampliação de Reminiscências de Viagens e Permanência no Brasil, escrito por Kidder e publicado em 1845, Brasil e os Brasileiros alcançou uma nova dimensão pelas mãos de Fletcher. 0 livro alcançou, pelo menos, nove edições durante sua vida (oito somente entre 1857 e 1868 e mais uma em 1879), atingindo um público bastante amplo nos Estados Unidos, Brasil, Inglaterra, e mesmo em outros países. 0 jornal Iondrino Athenceum, na resenha da $1^{\text {a }}$ edição, considerou o livro o retrato mais completo, fiel e artístico já produzido a respeito do Brasil. ${ }^{36} \mathrm{~A} 6^{\mathrm{a}} \mathrm{e}$ a $7^{\text {a }}$ edições foram publicadas com intervalo de pouco mais de um ano, sendo logo esgotadas. Partes do livro foram traduzidas para vários idiomas, incluindo a tentativa de uma edição completa em francês. ${ }^{37}$ Mesmo um biógrafo de Kidder (seu genro) considerou que Brasil e os Brasileiros ultrapassou o antecessor, afirmando também que o livro havia se tornado o texto imbuído de maior autoridade sobre o tema, inclusive influenciando o parlamento inglês em sua visão a respeito do Brasil. ${ }^{38}$ Muitos livros posteriores a respeito do Brasil, até o início do século $X X$, utilizavam Fletcher como referência em tópicos bastante variados. ${ }^{39}$ Cito aqui alguns exemplos:

Quando Fletcher (Brazil and the Brazilians) visitou São Paulo em 1855, ele fez a viagem desde Santos em cela de cavalo pela Estrada da Serra, destacando a excelência da seção na planície de Cubitao (sic); ele demorou dois dias na jornada e diz que a estrada "que atravessa estas montanhas é provavelmente a melhor do Brasil, com exceção da Estrada Imperial para Perópolis. ${ }^{40}$

Os notáveis e variados usos para os quais os nativos tomam esta árvore, de todas a mais regiamente bela neste país de exuberante e amável silvicultura e flora, são dados pelos narradores Fletcher e Kidder em seus esclarecedores esboços históricos e descritivos do Brasil em seus dias imperiais. ${ }^{41}$

No início da década de cinqüenta, Rev. J. C. Fletcher, um Presbiteriano, trabalhou por um breve período de tempo [no Brasil]. Ele estabeleceu uma relação peculiar com o imperador e mais tarde ingressou no serviço diplomático. ${ }^{42}$

Quem o vem confirmar ainda é o Rev. Fletcher, o autor do conhecido livro Brazil and Brazilians, falando em Boston sobre o "... Barão de Mauá, o grande financeiro e promotor das estradas de ferro no Brasil e presidente da Cia. de Navegação do Amazonas, homem de ideias liberais e de espírito elevado ...", com quem tivera 
FARIA, Alberto de. Irineo Evangelista de Souza, Barão e Visconde de Mauá. São Paulo: Companhia Editora Nacional, 1933. p.207.

44

JAMES, David. Op. Cit., p.271-272; KIDDER, D. P. FLETCHER, J. C. Op. Cit., ga ed., p.VI.

45

Um exemplo pode ser encontrado em CODMAN John. Ten Months In Brazil With Notes On The Paraguayan War. New York: James Miller, Publisher, 1872. p.41, p.149, p.180-181. Richard F. Burton, cônsul britânico em Santos e simpático sobre o trabalho de Kidder e Fletcher, fala de outros casos de autores críticos de Fletcher. Ver BURTON, Richard F. The Highlands of the Brazil. London: Tinsley Brothers, 1869, Vol.1, p.3.

46

JAMES, David. Op. Cit., p.145.

47

De modo geral, os missionários protestantes e brasileiros convertidos experimentaram pouca perseguição durante o Império e se surpreenderam com a liberdade garantida pela lei e pelas autoridades. Esta situação sofre alguma mudança (para pior) no início da República: com a perda de privilégio legal, parte do clero católico romano passou da polêmica verbal para a intimidação, espancamento, incêndio de igrejas $\mathrm{e}$, algumas vezes, assassinato de evangélicos (RIBEIRO, Boanerges. Igreja Evangélica e República Brasileira (1889-1930). São Paulo: Semeador, 1991. p.23-56). Começando pela chegada da família real portuguesa (1808), alguns grupos protestantes começaram a aportar no Brasil, protegidos pelo Tratado de Aliança e Amizade assinado por Portugal e Inglaterra em 1810, que em seu artigo XII concedia tolerância religiosa aos imigrantes protestantes. A partir de 1810, Anglicanos passaram "a celebrar o culto protestante a bordo de seus navios de guerra que ancoravam no porto do Rio de Janeiro ou em residências particulares, inclusive a de Lord Strangford." Locais de culto voltados para a capelania sujeitos às restrições do Tratado de Comércio de não terem forma exterior de templo foram construídos a partir de 1819 no Rio de Janeiro, Recife e Bahia (RODRIGUES, J.C. Religiões Acatólicas no Brasil, 1500 - 1900. Rio de Janeiro: Escriptorio do "Jornal do Commercio", 1904. p.95-96). A constituição de 1824 promulgada por D. Pedro I mantinha em seu artigo 5 aspectos da liberdade religiosa concedida por D. João VI: "A Religião Católica Apostólica Romana continuará a ser a religião do Império. Todas as outras religiões serão permitidas com seu culto doméstico ou particular em casas para isso destinadas, sem forma alguma exterior de templo" (Constituicão Politica do Imperio do Brazil de 25 de Março de 1824). "A legislação avançada que, durante o longo reinado de $D$. Pedro II, protegeu as missões evangélicas da perseguição aberta e até mesmo colocou as comunidades não-católicas sob a proteção das autoridades imperiais" (BRAGA, Erasmo \& GRUBB, Kenneth G. Op. Cit. p.49). Robert Kalley reagiu às perseguições que inicialmente sofreu em Petrópolis formulando uma série de questões sobre as suas atividades e apresentando-as simultaneamente aos Drs. Joaquim Nabuco, Urbano S. Pessoa de Melo e confabulações no Brasil a respeito das linhas para o seu país - acabando, com esta proposta à Comissão do Comércio (board of trade) de Boston. ${ }^{43}$

Reminiscências de Viagens e Permanência no Brasil abria suas primeiras páginas com retratos da família imperial brasileira: D. Pedro II e suas duas irmãs, d. Januária e d. Francisca, mostrados ainda crianças. Brasil e os Brasileiros seguiu este padrão, apresentando desde a primeira edição de 1857 em suas primeiras páginas um retrato de D. Pedro II, agora adulto. $\mathrm{Na} 9^{a}$ edição, de 1879, o retrato envelheceu, mostrando D. Pedro II já como um senhor de barbas brancas. A fotografia utilizada (autografada "D. Pedro d'Alcântara") foi um presente do imperador para o missionário, oferecida a este quando d. Pedro II o visitou em Portugal em $1877 .{ }^{44}$

Brasil e os Brasileiros, como o próprio subtítulo diz, traz informações históricas e descritivas sobre o Brasil. Alguns contemporâneos consideravam que Fletcher disfarçava ou mesmo distorcia a realidade do Brasil, apresentando o país "através de lentes cor de rosa"45. 0 próprio Fletcher, consciente destas observações (ou acusações), não se via como desonesto: apresentava aquilo que considerava ser não apenas a realidade como também o potencial do Brasil. Em 1866, em correspondência ao imperador, enviou a $6^{\text {a }}$ edição do livro desculpando-se por algumas partes recém acrescentadas que não pintavam uma realidade idilica do país (Fletcher não esclarece a que partes do livro se refere). Mas usando a sabedoria salomônica acrescentava "melhor é a repreensão feita abertamente do que o amor oculto. Quem fere por amor mostra lealdade, mas o inimigo multiplica beijos"46. Ou seja, o autor de 0 Brasil e os Brasileiros não deve ser entendido como um historiador ou cientista social na concepção atual destes ofícios, mas sim como um ativista com um programa a cumprir através das páginas de seu livro: promover o Brasil, as relações deste com os Estados Unidos, e, sobretudo, sua concepção pessoal do evangelho, unindo progresso material e espiritual. Não pretendo aqui fazer uma avaliação completa do livro, mas gostaria de destacar alguns tópicos que penso serem mais relevantes para encaixar Fletcher entre os pensadores da política brasileira.

Os capitulos de 3 a 5 concentram boa parte do "esboço histórico" do título, do descobrimento até a coroação de d. Pedro II. A história do Brasil conforme narrada por Fletcher passa por fatos básicos como as primeiras tentativas de colonização, o desenvolvimento do Rio de Janeiro e a independência, dando especial atenção à França Antártica. Essa história culmina com uma comparação entre o então atual estado do Brasil e de seus vizinhos hispânicos (especialmente o México, supostamente mais apto para desenvolver o argumento em razão das semelhanças em extensão territorial, população e recursos), destacando a superioridade do Brasil nesta comparação.

Fletcher considera que há um ingrediente racial nesta diferença entre descendentes de portugueses e espanhóis (assim como entre estes e anglosaxões), assim como uma diferença na forma de governo (os brasileiros optaram corretamente pela monarquia, mais apropriada para os latinos), mas principalmente que a diferença é de organização política: a constituição brasileira oferece um nível maior de democracia (caracterizada, por exemplo, na liberdade religiosa presente no Brasil e ausente no México ${ }^{47}$ ). Neste sentido ele oferece uma visão original que o distingue de outros pensadores da política brasileira naquele período: não há uma "sociologia 
Caetano Alberto Soares, juristas de destaque no período. Em resposta às questões de Kalley, eles emitiram pareceres altamente satisfatórios a favor da liberdade de pregação aos brasileiros (SIMONTON, Ashbel Green. O Diário de Simonton (1852-1866). $2^{\text {a }}$ edição revisada e ampliada com mapas e fotos. São Paulo: Casa Editora Presbiteriana, 2002. p.140).

48

LYNCH, Christian Edward Cyril. Saquaremas e Luzias: a sociologia do desgosto com o Brasil. Insight Inteligência (Rio de Janeiro), Vol.55, p.2137, 2011.

49

KIDDER, D. P.; FLETCHER, J. C. Op. Cit., $1^{\text {a }}$ ed. p.77-79.

50

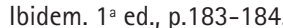

51

NABUCO, Joaquim. Um estadista do Império. Rio de Janeiro: Nova Aguilar, 1975. p.663.

52

KIDDER, D. P.; FLETCHER, J. C. Op. Cit., $1^{\text {a }}$ ed., p.182-183.

53

Fundada na Filadélfia em maio de 1817, a American Sunday School Union surgiu como uma coalizão de grupos de escola dominical locais. Seus objetivos eram promover 0 estabelecimento de classes de escola dominical e prover comunidades com bibliotecas e material para instrução religiosa. Desde seu início foi uma organização interdenominacional, deixando de lado as diferenças doutrinárias para alcançar um número maior de pessoas. Após diferentes modificações em sua organização, continua em atividade com o nome de American Missionary Fellowship. http://www.americanmissionary.org/ whoweare.shtml. Acesso em 22 de setembro de 2012. do desgosto com o Brasil"48, ao contrário: há um elogio a um país superado somente pelos anglo-saxões em sua democracia. ${ }^{49}$ Esta opinião foi firmemente mantida pelo autor ao longo das edições do livro.

A respeito dos partidos políticos brasileiros o missionário expressa uma opinião bem diferente de Kidder, seu predecessor. Kidder usa uma fonte "competente" para afirmar que não existem partidos de verdade no Brasil, mas sim facções sem programa definido, guiadas por antipatias e predileções pessoais que estragam qualquer tentativa de concerto político sadio. Fletcher expressa uma opinião na edição de 1857 que praticamente não foi alterada com os anos, sofrendo apenas pequenas atualizações nas edições seguintes do livro. Há alguma reminiscência das observações de Kidder, mas estas são atualizadas (ou corrigidas): se no passado as lutas partidárias pareciam corresponder à descrição do autor decano, de 1857 em diante as coisas eram diferentes: havia princípios sendo debatidos, não apenas luta por controle do governo. Há uma observação muito breve na edição de 1857 a respeito de uma profunda mudança dos princípios adotados pelos Saquaremas (não esclarecida) que desaparece nas edições de 1866 em diante.

A descrição de Fletcher a respeito do sistema partidário brasileiro é bastante simples: há dois partidos, os Conservadores (Saquaremas) e os Liberais (Luzias), ora governo, e ora oposição. Os Luzias se esforçam para promover o bem-estar do Brasil através da adoção de leis e regulamentos para as quais os Saquaremas não acham que o país esteja preparado. ${ }^{50}$ Não é uma avaliação muito diferente daquela realizada por políticos brasileiros: basta pensar que $04^{\circ}$ poder, exercido pelo imperador, tinha justamente a função de ser "moderador".

A respeito das eleições, mais uma vez a opinião de Fletcher é positi$\mathrm{va}$, ainda que as lentes utilizadas não sejam exatamente cor de rosa. José Tomás Nabuco de Araújo (1813-1878), o estadista do império, proferiu em 1866 o discurso dos sorites, uma grande crítica liberal ao império, questionando principalmente a legitimidade (e não apenas a legalidade) do Poder Moderador. 0 discurso também toca nas eleições:

\begin{abstract}
Vede este sorites fatal, este sorites que acaba com a existência do sistema representativo: o Poder Moderador pode chamar quem quiser para organizar ministérios; esta pessoa faz a eleição; porque há de fazê-la; esta eleição faz a maioria. Eis aí está o sistema representativo do nosso pais. ${ }^{51}$
\end{abstract}

A opinião de Fletcher não é a mesma: o missionário narra que há tumultos e brigas em dias de eleição. Um dos maiores estranhamentos está no fato delas serem realizadas em igrejas, situação que, de qualquer forma, parece conferir maior reverência ao processo eleitoral. Há inclusive o reconhecimento de que há grande influência do governo sobre os resultados através dos políticos em cargos e da possibilidade de anulação das eleições suspeitas de fraude. Mas, embora as eleições no Brasil não sejam perfeitos exemplos de democracia, o comentário mais importante a ser feito é que elas não são muito diferentes daquelas realizadas nos EUA. ${ }^{52}$

\section{0 ilustre viajante: terceira viagem ao Brasil (1862-1863)}

Entre 1862 e 1863 Fletcher esteve de novo no Brasil, desta vez como agente da American Sunday School Union. ${ }^{53}$ Trabalhando como agente desse grupo missionário ele visitou seus colegas presbiterianos, Ashbel Green 
55

RIBEIRO, Boanerges. Protestantismo e Cultura Brasileira: Aspectos Culturais da Implantação do Protestantismo no Brasil. São Paulo: Casa Editora Presbiteriana, 1981. p.128; Idem. A Igreja Presbiteriana no Brasil, da Autonomia ao Cisma. São Paulo: Livraria 0 Semeador, 1987. p.9; FERREIRA, Júlio Andrade. História da Igreja Presbiteriana do Brasil. Volume 1. São Paulo: Casa Editora Presbiteriana, 1992. p.78-79.

56

HILL, Lawrence F. Op. Cit., p.236.

57

VIEIRA, David Gueiros. Op. Cit., p.161.

58

Para uma discussão a respeito das diferentes correntes teológicas do presbiterianismo norte-americano naquele periodo ver RIBEIRO, Boanerges. A Igreja Presbiteriana no Brasil... Op. Cit., p.195-198.

59

KIDDER, D. P.; FLETCHER, J. C. Op. Cit., $6^{\text {a ed. }}$ p.160.
Simonton e Alexander Latimer Blackford, no Rio de Janeiro, assim como o missionário episcopal Richard Holden, em Belém do Pará. ${ }^{54}$ Boanerges Ribeiro registra que inclusive pregou na Igreja Presbiteriana do Rio (a atual Catedral Presbiteriana, na Rua Silva Jardim, Centro do Rio de Janeiro), então situada em sede alugada na Rua Nova do Ouvidor (hoje, Travessa do Ouvidor), $31,2^{\circ}$ andar..$^{55}$

Neste período, a pedido do professor Louis Agassiz, ele navegou três mil e duzentos quilômetros pelo Amazonas recolhendo espécimes para estudos ictiológicos. 0 resultado desse trabalho foi a Expedição Thayer, comandada por Agassiz em 1865-1866. 0 historiador Lawrence Hill considera esta expedição científica o "incidente fortuito" que finalmente desencadeou a abertura do Amazonas ao comércio e navegação internacionais. ${ }^{56}$ Um elemento nada desprezível ao considerar-se a aproximação entre EUA e Brasil, portanto.

David Gueiros identifica uma crise entre Fletcher e outros missionários nascida neste período. Em 1863, depois que foi visitado por Fletcher, Simonton escreveu uma longa e amarga carta contra o colega, acusando-o de "mundanismo" e de não assistir aos serviços religiosos aos domingos. Simonton chamou a campanha de Fletcher para levantar fundos para sua obra missionária no Brasil de "maroteira religiosa" e descreveu o colega como um "estorvo religioso" que devia ser afastado. Blackford e o episcopal Richard Holden também tiveram diferenças com o capelão. Juntos escreveram diretamente a Fletcher uma carta com o intuito de expor-lhe o que acreditavam ser sua posição como missionário no Brasil. Blackford não entrou em detalhes sobre o que disse a Fletcher nessa correspondência, mas parece que era da mesma opinião de Simonton. Apesar da rejeição, Fletcher ajudou a Imprensa Evangélica, jornal publicado pelos missionários presbiterianos no Rio de Janeiro, conseguindo clichês de ilustrações de jornais dos Estados Unidos em 1865, e mais tarde mandou para seus colegas uma imprensa muito grande e completa que tiveram que vender em 1868, segundo alegaram, porque a conservação da mesma era muito dispendiosa. ${ }^{57}$

Acredito ser importante mencionar que as desavenças entre Fletcher e outros presbiterianos parecem ter desvanecido com os anos, e não seria exagero especular que tenham sido pontuais. Simonton já havia então tido uma diferença com o missionário escocês Robert Reid Kalley, em 1859, sanada fraternalmente. Blackford era (assim como muitos outros missionários) um convicto sabatista e adepto da ala old school (conservadora) do presbiterianismo norte-americano ${ }^{58}$ : suas diferenças com Fletcher seriam de se esperar, mas não devem ser superestimadas.

A 6a edição (1866) de 0 Brasil e os Brasileiros trás uma nota de pé de página narrando alguns progressos do protestantismo no Brasil. Menciona a existência de diversas igrejas protestantes integradas por brasileiros, a possibilidade de pastores poderem realizar cerimônias de casamento e a eficácia da tolerância religiosa preconizada pela Constituição. Menciona também a presença de vários pregadores europeus e norte-americanos no Brasil trabalhando com sucesso e o "razoável sucesso" do jornal Imprensa Evangélica. ${ }^{59}$

0 prefácio da $8^{a}$ edição (1868) trás uma informação mais significativa. Nele, Fletcher conta com tristeza sobre o falecimento de Simonton (em 1867), segundo ele, daqueles que se dirigiram dos EUA para o Brasil, o mais zeloso, sábio e bem sucedido em "ganhar almas". Neste necrológio Fletcher conta sobre a fundação da missão presbiteriana no Rio de Janeiro em 1859 

Imperial. Rio de Janeiro: Objetiva, 2008. p.689690; Academia Brasileira de Letras Disponivel em http://www.academia.org.br/abl/cgi/cgilua.exe/ sys/start.htm infoid=818\&sid=320. Acesso em 14 de julho de 2012. e o estabelecimento da Imprensa Evangélica (então descrito como uma ferramenta muito importante, por ampliar significativamente a pregação feita a partir do púlpito, e também como uma importante contribuição para a literatura evangélica em língua portuguesa). Fletcher conta também que recebeu de Simonton uma alegre carta poucos dias antes deste falecer, na qual declarava os muitos frutos da missão naquele ano de $1867 .{ }^{60}$

Finalmente, a nota da edição de 1866 mencionada acima foi bastante expandida na 9a edição (de 1879). Nesta, Fletcher destaca a missão da PCUSA (a igreja presbiteriana do norte dos EUA naquele período), da qual Simonton e seus amigos eram pastores, como a mais bem sucedida daquelas em atividade no Brasil, mencionando nominalmente Blackford, além de George W. Chamberlain e Francis Joseph Schneider como continuadores do trabalho de Simonton. Ele segue com os acréscimos, dizendo também que havia então diversas igrejas e escolas em crescimento no Rio de Janeiro, São Paulo, Minas Gerais e Bahia. Descreve a visita do imperador à futura Universidade Presbiteriana Mackenzie, em São Paulo, em setembro de 1878, então dirigida pelo Rev. John Beatty Howell. Conforme Fletcher narra, na ocasião, D. Pedro II declarou abertamente que aquela era a melhor escola da categoria que jamais havia visto (considere-se aqui que o imperador já havia então viajado para a Europa e Oriente Médio (18711872) e os EUA (1876, de onde mais uma vez partiu para a Europa), lugares onde visitou muitas escolas). Por fim, Fletcher menciona também a "bem sucedida" missão da Presbyterian Church in the United States (ou PCUS a igreja presbiteriana do sul dos EUA naquele periodo), notadamente pela escola em Campinas sob direção de George Nash Morton e Edward Lane. ${ }^{6}$

Seja como for, a rejeição que Fletcher experimentou em 1863 entre outros presbiterianos teve um significativo contrapeso em Aureliano Candido Tavares Bastos, deputado alagoano, e um dos principais líderes liberais de seu tempo. 0 missionário encontrou então no deputado um fervoroso defensor de causas liberais, especialmente a abolição da escravidão, a imigração, a livre navegação do Amazonas, a educação, a liberdade de culto e a defesa dos protestantes. Com isso, parece ter conseguido um importante aliado dentro do governo brasileiro. ${ }^{62}$

Tavares Bastos é bastante conhecido dos historiadores. Advogado, político, escritor e jornalista, Aureliano Cândido Tavares Bastos nasceu na Cidade das Alagoas, hoje Marechal Deodoro, AL, em 20 de abril de 1839, e faleceu em Nice, França, em 3 de dezembro de 1875. Filho do deputado provincial José Tavares Bastos e de Rosa Cândida de Araújo, ele pertencia a uma família de prestígio na região. Ingressou na Faculdade de Direito de Olinda em 1854 (ano em que a faculdade se transferiu para o Recife), aos 15 anos, transferindo-se no ano seguinte para a de São Paulo, onde se bacharelou em 1858, já defendendo ideias liberais. Na faculdade estabeleceu importantes relações políticas que 0 acompanhariam durante sua carreira: Lafayette Rodrigues Pereira, Silveira Martins, Paulino de Sousa, Ferreira Viana, Afonso Celso (pai), Tomás Coelho, Macedo Soares, Pedro Luís. Seguindo os passos do pai, ingressou na carreira política. Foi eleito deputado geral por Alagoas em três legislaturas consecutivas, 1861-1863, 18641866 e 1867-1870, sempre pelo Partido Liberal, sendo na primeira vez, aos 22 anos de idade, o mais jovem deputado no Parlamento, eleito juntamente com José de Alencar, João Alfredo, José Bonifácio, o Moço, entre outros. ${ }^{63}$

Conforme já foi mencionado aqui, em sua primeira passagem pelo Brasil, entre 1852 e 1854, Fletcher debruçou-se sobre a abertura do Rio 
64

VIEIRA, David Gueiros. Op. Cit., p.95-96.
TAVARES BASTOS, Aureliano. Cartas do Solitário. $4^{\mathrm{a}}$ ed. São Paulo: Companhia Editora Nacional, 1975 [1862]. p.280-281.

66

Ibidem, p.331.
Amazonas ao comércio e navegação internacionais, enfrentando opiniões contrárias entre os brasileiros e projetos flibusteiros entre os norte-americanos. Comentei também que naquela época Fletcher escreveu em jornais do Rio de Janeiro a respeito deste assunto.

Tavares Bastos tinha apenas 14 anos em 1853, e não parece que os dois tenham se encontrado pessoalmente antes de 1862 (Fletcher estava fora do Brasil entre 1856 e 1862). Mas David Gueiros conjectura que, sendo Tavares Bastos um ávido leitor dos jornais, não deve ter deixado de ler estes artigos e se informar, por exemplo, sobre a exposição industrial de 1855 organizada pelo missionário, e suas demais ações em sua campanha pelo "progresso". Embora Tavares Bastos nunca tenha mencionado diretamente esses artigos de Fletcher em seus escritos (possivelmente porque 0 capelão escrevia sob um pseudônimo), a influência do missionário sobre o político alagoano se faz clara. ${ }^{64}$

Seja como for, Fletcher é mencionado por Bastos nas Cartas do Solitário, um dos seus principais escritos. Bastos recebeu o grau de Doutor em Direito em 1859; logo depois passou a residir no Rio de Janeiro, onde foi nomeado oficial de secretaria da Marinha e eleito deputado geral por Alagoas para sua primeira legislatura. Em 1861 publicou o panfleto "Os males do presente e as esperanças do futuro", com o pseudônimo de "Um Excêntrico", o primeiro dos trabalhos que o tornariam famoso como publicista. No mesmo ano foi exonerado do cargo de oficial de secretaria da Marinha, em represália contra um discurso que proferiu contra seus superiores. Em protesto, publicou entre setembro de 1861 e abril de 1862 uma série de 30 artigos de cunho liberal no Correio Mercantil, as chamadas "Cartas do Solitário", reunidas em um livro em maio de 1862.

$\mathrm{Na}$ Carta 23 (de 21 de março de 1862) Bastos trata da abertura do Rio Amazonas ao comércio e navegação internacionais. Aqui está um trecho:

Eis como o Union de Washington, em dezembro de 1852, justificava o direito dos Estados Unidos à navegação interior do Brasil: "As correntes do Mississipi e do Amazonas convergem em um ponto não longe de Cuba, e o barco norte-americano e a canoa do Amazonas entregues à sorte e às correntes encontrar-se-iam naquele rendez-vous. E, pois, aos Estados Unidos, mais que a nenhum outro povo, pertence a riqueza do Amazonas". Certamente, a imprensa americana transviou-se e, abandonando o terreno do raciocínio, preferiu muitas vezes favonear o espírito flibusteiro. Não se julgue, porém, que essas fossem as únicas manifestações públicas sobre a questão.

No capitulo final da obra Brazil and Brasilians, o sr. Fletcher fez justiça a essas exagerações, insistindo ao mesmo tempo nas grandes vantagens da abertura do Amazonas ao comércio estrangeiro.

É com efeito um erro acreditar-se que todo o americano é flibusteiro, e que a divisa política da pátria de Washington, Franklin e Jefferson é a invasão ou a conquista. Nada mais inexato. Ao contrário, a parte ilustrada do país, e sobretudo o Partido Republicano, professa os princípios de imparcialidade e paz de Monroe, proclamados solenemente na mensagem ao congresso em $1845 .{ }^{65}$

Conforme já foi citado aqui, o medo de que flibusteiros pudessem ameaçar o Brasil estava presente na década de 1850, de forma se não justificável, ao menos compreensível. Temia-se que o Brasil tivesse sua integridade territorial ameaçada, por exemplo, pela independência do Pará. Bastos identifica este temor, sobretudo entre os conservadores (ou saquaremas). ${ }^{66} 0$ que leva Bastos a pensar de forma diversa? Ou ao menos que exemplos ele apresenta de norte-americanos que contemporaneamente se 
GAYLE, Thornbrough; RIKER, Dorothy; CORPUZ, Paula (eds.). Op. Cit., Vol. IV, p.XII; Vol.V, 18531856, p.XX; Vol. VI, 1857-1860, p.XXI.

TAVARES BASTOS, Aureliano. Op. Cit., p.280-281.

69

Ibidem, p.331. comportam de forma diferente? Primeiro Fletcher e segundo o Partido Republicano, no qual o pai de Fletcher era um pioneiro: Calvin foi afiliado aos partidos anti-Jackson, Whig, Free Soil e Fusion (todos predecessores dos Republicanos) antes de apoiar os Republicanos a partir de 1856. Em 1860 apoiou a campanha presidencial de Abraham Lincoln. ${ }^{67}$

Em nota de rodapé de dezembro de 1862, acrescentada a $2^{\text {a }}$ edição do livro, Bastos faz mais uma observação:

Eis aqui as palavras do escritor amigo do Brasil [grifo meu]: "Brazil certainly has the right, and the sole right, to control the rivers within her own borders, no matter it they do rise in other states... Still, although we rejoice to see Brazil developing her own resources, it would be of incalculable benefit to herself as to the neighboring states if she would apply to the Amazon question the principles for which she contended on the La Plata, and throw the mighty river open to the commerce of the world". (Brazil and Brasilians. Philadelphia, 1859, pag.530-531.) 0 ilustre viajante, autor desse livro [grifo meu], acaba de percorrer o vale do Amazonas. As suas impressões e os seus escritos sobre essa parte do Império hão de ser provavelmente publicados na América do Norte, e não será esse o último importante serviço por ele prestado aos brasileiros [idem]. (Dezembro, 1862). ${ }^{68}$

Fletcher não é o único "amigo do Brasil" citado por Bastos em suas Cartas. Ele também faz referência à Thomas Rainey, o amigo de Fletcher (cooperador na redação de $O$ Brasil e os Brasileiros) já citado aqui. Na Carta 29 (de 28 de março de 1862) Bastos trata da navegação direta a vapor entre o Brasil e os Estados Unidos, assunto que liga à abertura do Rio Amazonas. $^{69} 0$ trecho a seguir é elucidativo:

Vários jornais americanos e a imprensa do Pará têm discutido esse objeto. Já citei o eloquente discurso do sr. deputado Tito Franco, na sessão de 1860. Os srs. Kidder e Fletcher, Hadfield e Dr. Thomas Rainey hão desenvolvido a matéria em seus livros ou em memórias especiais.

A ideia já entrou, demais, no círculo das operações práticas. Vários americanos, entre os quais o mesmo Dr. Rainey, dirigiram, em 1856, uma representação ao Congresso dos Estados Unidos, pedindo o subsídio de 180.000 , para o estabelecimento de uma linha de paquetes a vapor entre New York e Savannah nos Estados Unidos, e para ou Maranhão no Brasil, tocando nas ilhas de São Tomás e Barbados, em Demerara, e talvez também em outros lugares.

Informam-me que, posteriormente, outro empresário tentará fazer o mesmo serviço, mediante pequenas subvenções dos Estados Unidos, do Brasil, e da Dinamarca e Holanda, em cujas possessões deveriam os paquetes tocar.

Enfim, devo acrescentar que o próprio sr. Dr. Rainey, no mesmo intuito, ofereceu à presidência do Pará em 1855, e ao governo imperial em 1856, duas propostas ou memórias. Pessoa autorizada asseverou-me que o sr. Dr. Rainey não duvidaria estender o serviço até o Rio de Janeiro, se, além dos 360.000 que esperava do governo americano, o Brasil lhe garantisse apenas $100.000 \$$ mais. Creio que não poderia haver um negócio mais vantajoso. Vem a propósito recordar um fato. 0 sr. Rego Barros, no relatório com que, em 15 de maio de 1855, passou a seu sucessor a presidência do Pará, recomendou-Ihe especialmente a proposta do sr. Rainey, e já o tinha feito com todo o interesse ao governo central. É de notar que o sr. Rego Barros, homem de ideias práticas e apaixonado, como quase todos os seus comprovincianos, de melhoramentos materiais, é daqueles que admiram o progresso industrial dos Estados Unidos, não se temem de suas tão exageradas ambições, e desejam a abertura do Amazonas ao comércio universal. Quereis, porém, saber, meu amigo, a importância que o governo ligou à representação do sr. Rego Barros? Nem palavra se disse a respeito nos relatórios dos ministros ou na folha oficial, que também nada comunicaram ao país acerca da segunda representação do sr. Rainey! 0 vosso Correio Mercantil, porém, levantou a lebre 
e despiu a astúcia do governo. Em artigo de fundo, de 18 de julho de 1855, lastimáveis que os relatórios dos Estrangeiros e Império nada informassem a esse respeito. As palavras com que concluieis o artigo tornavam saliente o mistério do proceder do governo. Isso causou impressão no comércio da Corte; merecia uma resposta qualquer. Entretanto, o ministério guardou-se bem de dá-la pela folha oficial ou no Parlamento, que então funcionava. ${ }^{70}$

A história contada por Bastos demonstra que Rainey tinha múltiplos contatos com o Brasil antes de cooperar com Fletcher na redação de Brasil e os Brasileiros. Essa pode ter sido uma maneira através da qual Bastos o conheceu. Outra hipótese é que o alagoano o tenha conhecido através das próprias páginas de Brasil e os Brasileiros, nas quais Rainey é citado muitas vezes. Um ponto certo é que Rainey era muito importante para Bastos na defesa de suas idéias: Ocean Steam Navigation and the Ocean Post é a fonte utilizada por Bastos em Cartas do Solitário para defender a quebra do monopólio nacional sobre a navegação de cabotagem a vapor, abrindo a concorrência para empresas estrangeiras (das quais a de Rainey seria certamente uma boa opção). ${ }^{71}$

Não posso afirmar (ao menos não nesta etapa da pesquisa) que as ideias de Tavares Bastos sobre este e outros assuntos sejam produto da influência de James Cooley Fletcher. Há outras hipóteses a serem consideradas, mais plausiveis até. Mas no mínimo é importante (e curioso) notar como as ideias do político alagoano e do missionário norte-americano convergiam.

0 ponto principal aqui é questionar se Fletcher não teria sido uma peça na "americanização" do ideário político brasileiro. Ao menos em relação a Tavares Bastos parece ter exercido alguma influência. Nas palavras do alagoano, "0 que é, porém, esse país republicano que tanto terror inspira às imaginações dos nossos estadistas?"72.

\section{Quarta viagem (1864-1865)}

James Cooley Fletcher esteve no Brasil pela quarta vez entre 1864 e 1865, desta vez como enviado do Departamento de Estado norte-americano para trabalhar junto ao Parlamento brasileiro, defendendo o estabelecimento de uma linha de vapores ligando Rio de Janeiro e Nova York. Seu envolvimento no projeto era tal que, escrevendo ao conselho da missão, Ashbel Green Simonton informou que Fletcher havia derrubado o Gabinete Zacarias de Góis e Vasconcelos por causa de sua oposição à linha de vapores. 0 Gabinete Zacarias chegou ao poder em franca oposição às ideias de Tavares Bastos, Tito Franco de Almeida e seus amigos a respeito da abertura do Amazonas e linhas de vapores. Estes e outros liberais reuniram-se para derrubá-lo. 0 Gabinete seguinte, liderado pelo Senador Francisco José Furtado, aprovou a linha de vapores ligando Nova York e Rio de Janeiro. Simonton escreveu então ao conselho da missão:

0 projeto da linha de vapores foi aprovado em ambas as casas aqui e já é lei. Mr. Fletcher tem, sem dúvida, uma maravilhosa influência no Brasil...Espero que essa linha venha a ser um grande sucesso, mas não posso sentir-me confiante disto. ${ }^{73}$

0 envolvimento com este projeto não afastou Fletcher e D. Pedro II. Neste período o missionário esteve várias vezes com o imperador, como atestam suas correspondências. ${ }^{74}$ Já em relação a Zacarias de Góes e Vasconcelos não se pode dizer o mesmo. Aparentemente o missionário e 0 político baiano tornaram-se antagonistas neste período. 
75

A respeito do poder moderador ver $\mathrm{LYNCH}$, Christian Edward. O momento monarquiano: o poder moderador e o pensamento político imperial. Tese de doutorado. Instituto Universitário de Pesquisas do Rio de Janeiro, Rio de Janeiro, 2007

SOUSA, Paulino José Soares de, Visconde de Uruguai. Ensaio sobre o Direito Administrativo. Rio de Janeiro: Ministério da Justiça, 1960 [1862].
Zacarias de Góes e Vasconcelos nasceu na Bahia em 1815 e faleceu no Rio de Janeiro em 1877. Bacharel e doutor em Direito pela Faculdade de Recife/Olinda, onde também foi professor, Zacarias entrou para a política no Partido Conservador, mas passou para a Liga Progressista em 1861 e acabou se tornando um dos principais lideres do Partido Liberal em seu tempo. Passou por muitos cargos na administração pública, culminando com a chefia do Gabinete de Ministros em três ocasiões: 1862, 1864 e 1866. Ao longo de sua carreira política Zacarias tornou-se opositor de D. Pedro II. Em sua carreira parlamentar destaca-se o livro Da Natureza e Limites do Poder Moderador, de 1860. 0 texto é bastante difícil, mas a mensagem é simples: o rei reina, mas não governa. Esta é a interpretação que Zacarias queria propor para as atribuições do Poder Moderador, previsto na Constituição de 1824. Nas palavras do ministro, "a irresponsabilidade [do imperador pelos atos de governo] só se explica, ou só se compreende, como ausência da própria autoridade. Irresponsabilidade com autoridade significa tão somente despotismo".

0 Poder Moderador chegou ao Brasil inspirado nas ideias de Benjamin Constant (1767-1830). Este trabalhou sobre a divisão de poderes de Montesquieu, propondo um poder neutro ou moderador exercido pelo rei, atuando em teoria fora da esfera de poder e não sujeito à barganha política e à disputa político-partidária. No Brasil o Poder Moderador seria taxado "a chave de toda organização política", e o Imperador uma "figura inviolável e sagrada, sem responsabilidade pelos atos de governo". Ao longo do tempo surgiram discussões a respeito da separação entre os poderes Executivo e Moderador, ambos exercidos pelo Imperador, "chefe do Poder Executivo", através de seus ministros. 0 paradoxo se encontrava no fato de o imperador ser ao mesmo tempo responsável (no caso do Executivo) e irresponsável (no caso do Moderador) pelos atos de governo. 0 debate a respeito do Poder Moderador tornou-se central e polarizou opiniões, em detrimento de tópicos debatidos em outros países, como os direitos civis. ${ }^{75}$

Fletcher menciona o Poder Moderador apenas de maneira muito superficial em Brasil e os Brasileiros. A primeira edição do livro era de 1857, e este debate só se tornaria acalorado na década de 1860. Além disso, o livro não tinha o caráter de debate político e jurídico de outras publicações. Mas é possivel ler algumas coisas nas entrelinhas: embora fosse liberal (ou Luzia) em suas ideias (à moda de Tavares Bastos), Fletcher era também amigo e admirador de D. Pedro II. Incentivava reformas no Brasil ao mesmo tempo em que acreditava que o imperador tinha a competência de realizá-las. Embora não haja no livro uma menção direta disto, é razoável supor que sua opinião neste tópico estava mais próxima de Paulino José Soares de Souza, Visconde de Uruguai, e outros Conservadores (ou Saquaremas): "o rei reina, governa e administra". 0 Visconde de Uruguai defendeu esta tese em Ensaio sobre o Direito Administrativo, de 1862, publicado em resposta ao livro de Zacarias. Uruguai reiterou idéias já defendidas por José Antônio Pimenta Bueno, Marquês de São Vicente (1803-1878), em Direito Público Brasileiro e Análise da Constituição do Império, de 1857. Sentenciou ainda que "o poder político é a cabeça, a administração, o braço". 0 livro ajudou a firmá-lo na "Trindade Saquarema", como um dos mais importantes líderes conservadores de seu tempo. ${ }^{76}$

Na primeira edição de Brasil e os Brasileiros Zacarias foi mencionado por Fletcher como um dos mais importantes estadistas do Brasil, caracterizado como um "brilhante orador". Em uma lista de estadistas destacados figurava em 9a lugar. Na edição de 1879 o político baiano havia "perdido 
77

KIDDER, D. P.; FLETCHER, J. C. Op. Cit., $1^{\text {a }}$ ed. p.184-186.

78

JAMES, David. Op. Cit., p.272.

79

Ibidem, p.58-60.

80

VIEIRA, David Gueiros. Op. Cit., p.76-78.

JAMES, David. 0p. Cit., p.70-71, correspondência de 23 de abril de 1865

82

VIEIRA, David Gueiros. Op. Cit., p.110. colocações" indo para a 13a posição, além de ser caracterizado como "frequentemente acusado de relações jesuíticas"77, palavras que o missionário também usou em correspondência privada com o imperador no mesmo ano. ${ }^{78}$

Fletcher deixou o Brasil com destino à Europa em 26 de setembro de 1864. Na Inglaterra, em Outubro e Novembro daquele ano, proferiu uma série de palestras sobre o Brasil e intermediou a eleição de D. Pedro II como membro honorário da Royal Geographic Society de Londres. ${ }^{79}$

Em 1865 o missionário estava de volta no Brasil para receber o professor Agassiz no Rio. Em 28 de maio um jantar foi realizado para celebrar o aniversário do cientista, contando com a presença de Fletcher e outros missionários. Conforme mencionado anteriormente, a viagem de Fletcher pela Amazônia entre 1862 e 1863 preparou caminho para a Expedição Thayer, comandada por Agassiz em 1865-1866. David Gueiros considera a Expedição Thayer a grande vitória do missionário na sua posição de agente do "progresso". Poderiamos colocar essa afirmação de outra forma, e dizer que foi uma grande vitória em sua posição de lobista por melhores relações diplomáticas entre Brasil e Estados Unidos. De acordo com o historiador, o envolvimento de Fletcher com a expedição científica de Agassiz foi tal que a julgar pela documentação disponível "parecia aos seus amigos brasileiros que a mesma era mais um dos seus feitos"80.

Fletcher apressou-se em desfazer impressões exageradas sobre seu papel na visita de Agassiz ao Brasil - o Diário do Rio de Janeiro chegou a publicar a notícia de que ele estava no Rio para apresentar o cientista, o que ele negou em correspondência com o imperador, afirmando que Agassiz dispensava apresentações. ${ }^{81}$ Ainda assim é claro que o missionário usou a Expedição Thayer e o prestígio de Agassiz para promover diversos dos projetos que havia anos defendia nos Estados Unidos e no Brasil: a emancipação dos escravos, a abertura do Amazonas à navegação internacional, a Sociedade de Imigração Internacional e a linha de vapores entre Nova York e Rio de Janeiro.

Fletcher envolveu-se com este último projeto ao ponto de seus colegas presbiterianos se referirem a este como "Mr. Fletcher's steam project". Esta impressão foi compartilhada pelo jornal The Anglo-Brazilian Times que em 1865, de maneira irônica, saudou a chegada do pastor ao Rio de Janeiro mencionando seu "falar blandicioso" com que iria persuadir deputados e senadores a votar a favor da linha de vapores. ${ }^{82} \mathrm{Em} 8$ de julho de 1865 ele mais uma vez deixava o Brasil com destino à Europa.

A partir de então, mesmo afastado do Brasil, Fletcher se envolveu na Guerra do Paraguai (1864-1870), principalmente através de trabalho jornalistico e das edições subsequentes de Brasil e os Brasileiros. Enquanto que as primeiras edições do livro nada poderiam mencionar a respeito deste conflito, a de 1866 vinha com grande quantidade de informação (especialmente em notas de rodapé acrescentadas ao texto original) nas quais o missionário defende o Brasil. Ainda insatisfeito com seus esforços em favor do Império, Fletcher chegou a escrever repetidas vezes a Dom Pedro II desculpando-se pelo pouco que havia feito no livro, acrescentando que vinha nos EUA declarando francamente suas convicções a respeito da iniquidade do Paraguai. Aproveitava para remeter ao imperador matérias publicadas por ele em jornais norte-americanos defendendo o Brasil, acrescentando que estas tinham o efeito de fazer "baixar o tom" de outros jornais americanos a respeito do Paraguai. Enviou ainda o prefácio que fizera para a $8^{a}$ edição de Brasil e os Brasileiros. ${ }^{83}$

A Guerra do Paraguai não foi o primeiro conflito brasileiro comentado por Fletcher em seu livro. A guerra contra o argentino Juan Manuel Ro- 
KIDDER, D. P.; FLETCHER, J. C. Op. Cit., ga ed. p.351-353.

85

A percepção negativa a respeito de Washburn ainda seria sentida muitos anos depois. Para um exemplo disto ver PRADO, Eduardo. A Ilusão Americana. São Paulo: Brasiliense, 1957 [1893].

JAMES, David. Op. Cit., p.184-186.

VIEIRA, David Gueiros. 0p. Cit., p.73. sas já havia recebido um tratamento semelhante..$^{84}$ As opiniões de Fletcher a respeito da Guerra do Paraguai, porém, tiveram o agravante de colocá-lo em choque com o General James Watson Webb, diplomata norte-americano em serviço no Rio de Janeiro (1861-1869), e com Charles A. Washburn, ministro norte-americano no Paraguai. Webb e Washburn trouxeram problemas para as relações entre Estados Unidos e Brasil, pressionando o governo brasileiro por retribuições em casos de navios norte-americanos prejudicados pelo conflito no Prata. E não apenas isto: o público norte-americano possuía a tendência de atribuir a culpa pelo conflito ao Brasil, sendo incapaz de imaginar que o pequeno Paraguai pudesse ser o agressor; esta impressão era reforçada por declarações iniciais de Washburn. ${ }^{85}$

Assim como ocorrera com Trousdale, as investidas de Fletcher para retirar Webb do Brasil podem ter sido motivadas por desaprovação da diplomacia e também por questões pessoais. Em 1861 o general havia pedido a William H. Seward, secretário de Estado dos EUA, que rescindisse a nomeação de Fletcher como Primeiro Secretário da Legação. Escrevendo a d. Pedro II, em 1868, Fletcher critica Webb por este se vangloriar de poder fazer o que quiser com o imperador e com o Brasil. De acordo com o missionário, Webb só estava no Brasil porque Seward o achava um chato e o queria bem longe dos Estados Unidos. Na correspondência, Fletcher menciona ainda que havia feito uma palestra na Brooklyn Historical Society a respeito da presença holandesa no período colonial brasileiro e que pretendia estar no Brasil em breve. ${ }^{86}$

Não se pode deixar de observar que autores como Lawrence Hill e Bradford Burns, escrevendo de uma distância cronológica segura, demonstram opiniões semelhantes aos de Fletcher em relação à Webb. 0 retorno de Washburn aos Estados Unidos em 1868 e os relatos de Fletcher sobre as perdas de cidadãos norte-americanos sofridas nas mãos de Lopes ajudaram a modificar a opinião pública norte-americana, tornando-a mais favorável ao Brasil. 0 missionário, por sua vez, manteve a opinião de que graças a seus esforços pessoais havia acontecido a mudança de opinião nos Estados Unidos a respeito da guerra. Gueiros ressalta que o pastor pode ter exagerado neste ponto, mas que certamente "deve-se atribuir-lhe o mérito de ter, por três anos, quase sozinho, batalhado em favor do Brasil, através da imprensa americana"87.

Portanto, outro ponto significativo da atuação de Fletcher no Brasil se deu em seu envolvimento com a diplomacia entre os dois países. Algo já foi dito neste artigo a respeito de sua passagem oficial pela legação norte-americana no Rio de Janeiro e sobre seu trabalho como lobista a favor de empresas norte-americanas.

Ligado a este assunto, pode ser mencionado que, assim como outros missionários presbiterianos, Fletcher envolveu-se na migração de confederados para o Brasil. Porém, uma característica especial sua era que seu envolvimento era feito de maneira mais direta e explícita. Também seus amigos Agassiz e Tavares Bastos estiveram envolvidos na questão e cooperaram de maneira decisiva neste processo. Tavares Bastos, o "amigo a toda prova" dos presbiterianos foi aparentemente o principal articulador brasileiro da migração confederada. Em princípios de 1866 ele participou da fundação da Sociedade Internacional de Imigração, um grupo composto por brasileiros liberais e banqueiros e corretores estrangeiros para tratar da questão da imigração. 0 alagoano parece te sido a principal liderança da mencionada sociedade em seus anos de atividade. Dois grupos, com pontos de vista divergentes, tomaram parte na formação dessa sociedade. De um lado, um grupo favorável à imigração em geral. De outro, um grupo 
89

A American Tract Society é uma organização interdenominacional ainda em atividade. Tinha o objetivo de evangelizar através da circulação de panfletos religiosos. A primeira sede da ATS foi um prédio de quatro andares no número $87 \mathrm{da}$ Nassau Street em Nova lorque. Mais tarde, em 1894, os fundos monetários já eram suficientes para prover a construção de um prédio de 23 andares próximo à Broadway e à Quinta Avenida, na época de sua construção um dos prédios mais altos da cidade de Nova lorque e ainda hoje de pé. http://www.atstracts.org/readarticle.php?id=4. Acesso em 22 de setembro de 2012.

90

JAMES, David. Op. Cit., p.234-237.

91

Ibidem, p.271; CARVALHO, José Murilo de. Op. Cit., p.159. bem menor e estritamente pró-confederados, apoiado discretamente pelos presbiterianos e não tão discretamente por Fletcher. ${ }^{88}$

\section{Quinta viagem (1868-1869) e anos finais}

Entre 1868 e 1869 Fletcher faria sua última viagem ao Brasil, dessa vez como agente da American Tract Society. ${ }^{89}$ Foi então enviado como cônsul para o Porto, em Portugal, onde permaneceria até 1873. Como cônsul em Portugal recebeu D. Pedro II quando este visitava a Europa. ${ }^{90}$

Terminado seu trabalho diplomático em Portugal, ele retomou a carreira missionária em Nápoles, Itália, onde permaneceria entre 1873 e 1890, provavelmente outra vez trabalhando para a American and Foreign Christian Union. Aparentemente não pode encontrar-se com D. Pedro II quando este visitou os EUA em 1876, mas este certamente foi mais um evento que contou com sua contribuição: nesta viagem o imperador pode encontrar-se com vários dos amigos a ele apresentados por Fletcher. ${ }^{91}$

Em 1891 Fletcher fixou residência em Los Angeles, permanecendo ativo no ministério. Em 1895 tornou-se presidente da Los Angeles School of Art and Design e em 1898 recebeu o grau de LL.D. (um doutorado honorário) pela Brown University. Em seus anos finais destinou especial atenção a La Crescenta, uma pequena igreja de missão. Faleceu em Los Angeles, Califórnia, em 23 de Abril de 1901.

\section{Conclusão}

James Cooley Fletcher atuou no Brasil, com alguns intervalos, entre 1852 e 1869. Exerceu principalmente os papéis de missionário, diplomata e filantropo. Diria, porém, que a seu ver foi sempre um ministro do evangelho, um evangelho em uma visão particular, não tão exótica para a época em que viveu. Porém, neste aspecto se destacou da maior parte dos missionários que atuaram no Brasil dentro do mesmo periodo, em geral adeptos de uma visão mais tradicional do protestantismo, focada na conversão de indivíduos e não em transformações da sociedade, como queria Fletcher (ainda que não tenha em momento algum descuidado da parte mais tradicional de sua missão, como foi narrado aqui). Conforme dito na introdução, algumas atividades de Fletcher no Brasil se destacam mais do que outras. Algumas delas já estão mencionadas ao longo deste texto, como sua amizade com D. Pedro II e seu variado trabalho missionário em diferentes pontos do pais, assim como sua luta pela aproximação entre Brasil e Estados Unidos.

A contribuição de Fletcher como escritor de Brasil e os Brasileiros também deve ser destacada. Em um tempo de relações bilaterais mornas entre os dois paises, Fletcher muito contribui para tornar o Brasil mais conhecido nos Estados Unidos. Conforme mencionado aqui, este trabalho teve impacto duradouro, com autores do início do século 20 ainda tomando Fletcher como referência.

Concluindo, Fletcher é um curioso e importante personagem do Segundo Reinado, e mesmo da história do Brasil como um todo. Foi também um pensador do Brasil, alguém que deu sua contribuição para nosso imaginário como nação. É importante notar que o caráter aparentemente inocente de seu livro, um relato de viagem, pode passar despercebido quando se considera este último ponto. Mas o fato é que este "turista" ou "clérigo" deu ao Brasil e às relações com os EUA uma contribuição insuspeita para muitos. Acredito que estudos posteriores sobre este e outros missionários são válidos e que provavelmente trarão informações que podem enriquecer ainda mais a compreensão de diferentes aspectos do Brasil. 